\title{
Entre história e ficção: 0 fracasso do homem de exceção. Une saison au Congo (Aimé Césaire) e Lumumba (Raoul Peck)
}

Between History and Fiction: The Failure of the Exceptional Man. Une Saison au Congo (Aimé Césaire) and Lumumba (Raoul Peck)

Entre Histoire et fiction: l'échec de l'homme d'exception. Une Saison au Congo (Aimé Césaire) et Lumumba (Raoul Peck)

\section{Fabrice Schurmans}

\section{OpenEdition}

\section{Journals}

Edição electrónica

URL: http://journals.openedition.org/rccs/5888

DOI: $10.4000 /$ rccs. 5888

ISSN: 2182-7435

Editora

Centro de Estudos Sociais da Universidade de Coimbra

Edição impressa

Data de publição: 1 Maio 2015

Paginação: 85-104

ISSN: 0254-1106

\section{Refêrencia eletrónica}

Fabrice Schurmans, «Entre história e ficção: O fracasso do homem de exceção. Une saison au Congo (Aimé Césaire) e Lumumba (Raoul Peck) », Revista Crítica de Ciências Sociais [Online], 106 | 2015 colocado online no dia 28 abril 2015, criado a 20 abril 2019. URL : http://journals.openedition.org/ rccs/5888; DOI : $10.4000 /$ rccs. 5888 


\title{
FABRICE SCHURMANS
}

\section{Entre história e ficção: \\ O fracasso do homem de exceção. Une saison au Congo (Aimé Césaire) e Lumumba (Raoul Peck)}

\begin{abstract}
Este artigo analisa o modo como a tragédia de Aimé Césaire e o filme de Raoul Peck contribuem para a produção do discurso histórico relativo ao desaparecimento de Patrice Lumumba. Na primeira parte, abordo a ligação entre ficção e história à luz do debate contemporâneo relativo à capacidade de o romance fazer e dizer a história, assim como ao que a história retira da ficção. Na segunda parte, o texto incide sobre os contextos respetivos de ambas as obras, o que permitirá afinar a análise da peça e do filme. Por fim, na terceira parte, evidenciarei a maneira como Césaire e Peck representam a figura de Lumumba e reavaliam o passado colonial belga.
\end{abstract}

Palavras-chave: Aimé Césaire, 1913-2008; cinema; ficção; história colonial; Patrice Lumumba, 1925-1961; Raoul Peck, 1953.

\section{A literatura e a história}

Conseguirão a peça de Césaire e o filme de Peck dizer a história? Colocar esta questão implica não só perguntar o que distingue uma tragédia e um filme de ficção de uma obra histórica sobre o mesmo tema, mas igualmente o que esta última pode fazer em relação à ficção. Com esta reflexão sobre a relação da história com a ficção, sobre a maneira como a literatura consegue, num outro patamar de verdade, dizer a história, tocamos o cerne de um debate essencial que tem ocupado as ciências sociais e humanas. Não se trata aqui de pôr em evidência a relação entre literatura/cinema e história, mas de questionar especificamente a natureza desta relação hoje.

Desde finais do século XX assistimos, no campo da história, à aceleração de uma mudança de paradigma, uma mudança iniciada nos anos 70 . As noções emergentes sublinham a magnitude da crise: "crise do tempo", isto é, "crise do futuro" e "clausura do futuro" são expressões que remetem para o que está em jogo. Se a história se interroga regularmente, desde o século XIX, sobre os seus pressupostos teóricos, a sua filosofia, as bases da 
sua epistemologia, essa mesma história foi levada, no final do século passado, a duvidar da impermeabilidade das suas fronteiras a práticas afins, da sua capacidade de exprimir todo o passado, de apreender a natureza de certos acontecimentos violentos.

É certo que as regras da crítica histórica e as técnicas de investigação garantem ao historiador a possibilidade de trabalhar sobre um tópico apoiando-se nos pressupostos da sua ciência, mas, em determinados pontos, questionamentos precisos põem em causa as certezas. Dever-se-á notar, entre outras, a questão da escrita da história, a natureza e os limites da verdade resultante da operação histórica, o estatuto do testemunho e dos arquivos, a relação da história com a literatura. Este questionamento, simultaneamente epistemológico e filosófico, surge nos primeiros anos deste século no momento em que jovens romancistas investigam a história traumática do século xx, nomeadamente a Segunda Guerra Mundial e a Shoah, com o objetivo de dizer uma história que esses próprios autores não conheceram. Os escritores em causa voltam à história, apropriam-se de certas técnicas de investigação, trabalham os arquivos, num contexto social em que as testemunhas diretas praticamente já desapareceram. Esta literatura diz a história de maneira particular, revelando uma outra relação não com o tempo, mas com a memória do tempo que passa, com o que essa memória passou a significar para uma sociedade onde abundam os traços materiais do passado. Restam poucas dúvidas de que a literatura - mas o mesmo poderia ser dito sobre o cinema - investe no campo da história quando esta é confrontada com os seus limites epistemológicos.

Será um pouco vão, a partir deste ponto de vista, querer constituir história e literatura como par antitético, pois o que as distingue são, antes de tudo, regimes de verdade diferentes aos quais o recetor não atribui o mesmo alcance. Um romance, uma peça de teatro ou um filme sobre a Shoah apropriam-se de uma série de acontecimentos e de atores sociais a fim de os transformar em intriga e em personagens e, ao fazê-lo, criam discursos inscritos num contexto histórico que explica, em parte, o que esses discursos significam. A verdade de um tal texto de ficção é frequentemente acoplada às fontes históricas sem, no entanto, se tornar numa obra identificada como histórica. Quanto aos historiadores, confrontados com o acontecimento violento, socorrem-se da ficção com o objetivo de tornar sensível a palavra muda, nomeadamente a da vítima anónima.

É neste contexto de mistura de géneros e de práticas que se coloca com premência a questão da verdade, tanto a da história como a do romance. A verdade existe por si só, ou existirá uma verdade histórica e uma verdade literária (Coquio, 2013)? Não se esgotará a questão da natureza da relação 
da literatura com a história a tentar responder-lhe pois, como se sabe, estamos perante dois regimes de verdade diferentes, dois regimes de verdade que respondem a dois tipos de relação com a escrita, o que corresponde a um ponto central. A suposta neutralidade da escrita histórica, baseada numa confusão entre os pressupostos científicos que o historiador adota e a transposição para a escrita, não passa de uma miragem pois não existe uma escrita-tipo comum ao conjunto dos historiadores. É justamente isso que defende Patrick Boucheron, historiador da Idade Média, num contributo sobre a relação entre ficção e história:

A maneira com que o discurso do historiador garante a sua própria cientificidade e se demarca da invenção ficcional (ou simplesmente da suspeita que pesa sobre a possível indistinção entre o discurso verdadeiro e o discurso inventado) não é nada mais do que um processo narrativo [...]. (Boucheron, 2011: 49)

Por isso, o historiador escreve, utiliza processos narrativos, um estilo sóbrio e académico, sem dúvida, mas tratar-se-á de uma escrita do mesmo estilo da do romance? Pierre Nora tentou responder a esta questão apontando para um certo número de diferenças entre a escrita da história e a escrita romanesca. O problema é que, à semelhança dos que se debruçaram sobre esta questão, o que Nora propõe a propósito da especificidade da escrita histórica poderia, sem dificuldade, ser aplicado ao género romanesco.

Assim, argumenta que "[...] a história é o produto de um lugar social do qual emana, tal como os bens de consumo são produzidos por uma empresa: há uma fábrica da história” (Nora, 2011: 10). Poder-se-ia dizer precisamente o mesmo, por exemplo, de um romance policial ou de ficção científica, ou mesmo histórico. O autor acrescenta na mesma ocasião que "esta relação com o corpo social é o próprio objeto da história"; ora, o romance existe também e fundamentalmente em relação com o corpo social. Além disso, certas afirmações do historiador causam problemas num outro âmbito. Quando afirma, por exemplo, que "a história, de maneira distinta do romance que se pode escrever apenas com a finalidade da distração, certifica a existência de um mundo comum", poder-nos-emos questionar sobre que linha lógica Nora vê entre esse romance escrito com a finalidade da distração e a história que, essencialmente, confirma que partilhamos o mundo. Além disso, embora pretenda abordar a especificidade da escrita, fala da história não como escrita mas como disciplina e do romance não como prática literária mas como intenção (distrair o recetor).

Nota-se que, quando se trata de distinguir a história da literatura, não é raro o experiente historiador, ao reivindicar ser capaz de o fazer, contribuir 
ainda mais para a confusão. Mona Ozouf, por sua vez, julga ter encontrado a principal distinção entre as duas práticas na noção de verosimilhança. As benevolentes de Jonathan Littell serve aqui de contraponto. Se existir um só erro neste romance, defende Ozouf, então o leitor deve desconfiar do conjunto.

Aqui há uma fronteira cruzada, uma transgressão que abala a nossa crença de leitor. E esta simples observação basta para mostrar toda a distância que separa o discurso romanesco do discurso histórico: o historiador não pode fazer Danton casar com qualquer uma. O romancista pode, mas paga esta liberdade com o ceticismo do seu leitor. (Ozouf, 2011: 14)

Uma vez mais é o historiador que confunde aqui os dois níveis de verdade. $\mathrm{O}$ recetor, esse, sabe onde se encontra, sabe que tem um romance nas mãos, bem documentado certamente, mas um romance. Quando se trata, no mesmo lugar, de distinguir as práticas literárias e romanescas, Ozouf apoia-se primeiro em critérios de cientificidade (e.g. o historiador não pode evitar o referente, as datas e os feitos, as notas) antes de admitir que, no final de contas, tal pouco importa pois estamos perante dois tipos de relação com a verdade (Ozouf, 2011: 22). Quanto à escrita, Ozouf e Nora parecem não ver o essencial, nomeadamente que, se o historiador desenvolve um estilo - a "bela linguagem", isto é, a eloquência fruto do ensino, de trabalhos universitários, de leituras -, este distingue-se do trabalho literário sobre a língua.

Neste âmbito, a literatura e o cinema dizem a história, mas num contexto particular onde a memória (o lado afetivo da relação do homem com o seu passado) importa tanto como a história (a abordagem científica ao passado). E, se a noção de verdade está de regresso nos discursos e nas preocupações epistemológicas, fá-lo acompanhada de outras noções tais como memória justamente, mas também catarse, justiça, reparação (Coquio, 2013). A Europa no século xx, esse continente de trevas, como lhe chamou o historiador Marcus Mazower, pôs-se, sob o efeito da justiça, a voltar ao seu passado tanto através da memória como da história. Ricoeur identificou este momento de confusão em que emerge a noção de dever de memória, esta "memória compelida" posta em concorrência com a história concebida como disciplina científica. Esta injunção parece fixar os termos da alternativa: lembrar-se, através de uma multitude de comemorações e de cerimónias, ou estudar o passado em toda a sua complexidade. Ricoeur via neste dever um aspeto duplo, "como se impondo de fora ao desejo e como exercendo uma coação sentida subjetivamente como obrigação" (Ricoeur, 2000: 107). É do âmbito então da justiça conjugar estes dois aspetos a fim 
de permitir ao corpo social retirar da rememoração um ensinamento, bem como uma nova ética para o futuro. É certo que Ricoeur considera o dever de memória perante a Segunda Guerra Mundial, e nunca em relação ao colonialismo e aos seus crimes; contudo, as reflexões do filósofo ajudam a pensar uma França, uma Bélgica ou um Portugal pós-coloniais onde o Estado reconheça os seus crimes perante o Outro, o que - além da possibilidade de fazer justiça - favorece a emergência de uma história partilhada que deixe de ser uma história em conflito (ibidem: 108).

Recordar as vítimas da Shoah, sem dúvida, mas é necessário igualmente recordar o sofrimento ignorado, produzido em grande parte como não existente, desses Outros brutalizados pela Europa durante o período colonial. Como lembrou Raphaëlle Guidée (2013), é por as vozes das vítimas se apagarem que está emergindo a injunção imperiosa: é necessário contar, pois o esquecimento é quase tão monstruoso como o próprio crime. Face ao crescimento do número de vítimas e de oprimidos, acrescenta, tornou-se impossível para a história ter garantia exclusiva da verdade; o recurso à arte em geral, e à literatura em particular, torna-se indispensável se quisermos aproximar-nos um pouco mais da realidade do sofrimento. A literatura e o cinema encontram-se, desta maneira, na confluência das noções de regime de verdade, de memória e de história. Como veremos mais à frente, ambos participam da história, dizem parcialmente a história, e ao mesmo tempo coagem o recetor a lembrar-se de um passado mal conhecido e frequentemente manipulado por um discurso anterior.

Parece claro que Aimé Césaire e Raoul Peck dizem a história a partir de um outro ponto de vista, sem jamais perderem de vista a história hegemónica, mas - e esta questão é essencial - dizem-na num contexto diferente: o primeiro pega em Lumumba quando ainda não tinha tido lugar o ato de reparação da parte do opressor, o segundo quando o Estado belga analisa aprofundadamente a sua participação no crime e apresenta o seu pedido de desculpas à família e ao povo congolês (a reparação moral do crime cometido em relação aos outros de que falava Ricoeur). A partir deste ponto de vista, Césaire e Peck são ambos apanhados (e empenhados) na história fazendo, ao mesmo tempo, parte da história das suas práticas respetivas.

\section{A importância do contexto histórico para entender o propósito de Césaire e de Peck}

Para responder à questão colocada no início deste artigo é preciso ter em conta as especificidades dos dois meios, mas igualmente o contexto no qual as duas obras foram produzidas. A primeira versão da tragédia de Césaire data de 1966, momento em que Mobutu assegura o seu poder sobre o Congo, após 
o esmagamento da rebelião no Leste do país com a ajuda de tropas belgas. Contemporânea dos factos que servem de base à peça, esta descreve a queda de Lumumba, o homem de exceção, e a emergência de um poder neocolonial. Césaire conhece o papel desempenhado pelo Estado belga na morte do primeiro-ministro, sabe que sem esse papel teria sido difícil a Mobutu a ascensão ao poder e a sua manutenção. ${ }^{1}$ Quando apresenta a versão definitiva da peça em 1973, Mobutu, que seria em breve considerado "o dinossauro" por causa da sua longevidade política (Braeckman, 1992), reina incontestado sobre o Zaire, sempre com o apoio dos Estados Unidos, da França e, em menor grau, por causa das nacionalizações consecutivas à política de autenticidade, da Bélgica. Torna-se assim necessário reler esta peça à luz das descolonizações, das intervenções armadas das ex-potências coloniais e da instauração de regimes fortes estruturados em torno de partidos únicos.

Além disso, Une saison au Congo não faz realmente sentido se não for integrada no que denominamos dramaturgias da descolonização, um conjunto de textos, a maioria tragédias, que colocam em cena personagens de exceção empenhadas na luta pela independência dos seus países respetivos. Como outros dramaturgos dos mundos africanos e das Caraíbas, Césaire descreve uma personagem, neste caso Lumumba, resistindo, em nome do coletivo, à opressão colonial e neocolonial. Se, na sua tragédia, capta Lumumba no momento em que começa a sua vida pública em Léopoldville - Peck fará o mesmo - é por ter decidido descrever a curta carreira política e a morte daquele socorrendo-se da estrutura da narrativa messiânica. A sucessão de acontecimentos que conduzem à queda do ser de exceção - em fidelidade com a realidade - tendem a dotá-lo de um significado para a comunidade. Dito por outras palavras, a maioria destas personagens são apanhadas num jogo de tensões dialéticas, das quais não conhecem todas as regras e, por isso, acabam por morrer, mas esta morte, pelo seu lado sacrificial, acaba por apontar para a possibilidade de uma síntese superior, a da nação unida vivendo num Estado democrático. A figura, oscilando entre história e mito, dá assim sentido à coletividade. ${ }^{2}$

\footnotetext{
${ }^{1}$ Note-se que, para os observadores contemporâneos dos acontecimentos em questão, a colusão entre o ex-colonizador e certas elites locais era mais que óbvia (e.g. Fanon, 2006: 215).

${ }^{2}$ Foi o que notou precisamente um dos especialistas das dramaturgias africanas pós-coloniais: "A violência histórica, representada por intermédio do percurso excecional ou exemplar de uma figura heroica, encontra-se assim dotada de um sentido e articulada à figura de um sujeito em torno do qual a coletividade, presa nas garras da violência, descrita invariavelmente como desunida, é virtualmente capaz de se unir - a ponto de que este cenário pode figurar como invariante mítico das dramaturgias desta geração." (Mégevand, 2009: 96). Nisso, o teatro não difere do efeito criado pela vasta produção pictural relativa a Lumumba e oriunda dos mercados de Lubumbashi. Aqui, ao mesmo tempo, a arte é memória e diz uma outra versão da história (Jewsiewicki, 1996: 133-134).
} 
Se, em certos pontos, o filme de Peck segue a tragédia de Césaire, nomeadamente no que diz respeito à transformação de Lumumba em personagem messiânica, o contexto no qual se inscreve é diferente. Os anos 1990 marcam de facto uma viragem nas relações entre o Estado belga e a República Democrática do Congo (RDC). Uma série de fatores ocorridos na última década do século passado explica em grande parte a natureza dessas mudanças. Em primeiro lugar, deu-se em 1997 a queda do regime autoritário de Mobutu, através da pressão de uma rebelião dirigida por Laurent-Désiré Kabila e apoiada por países vizinhos, em que se incluía o Ruanda. Se a história das relações ambíguas entre o potentado pós-colonial e uma parte do mundo político belga ainda está por escrever, podemos já afirmar que as ligações entre os dois polos se tinham deteriorado fortemente depois do início dos anos 90, em consequência, entre outros, do massacre de estudantes na Universidade de Lubumbashi (11-12 de maio de 1990). É também necessário ter em conta a mudança, na Bélgica, da maioria política a nível federal em 1999, com a passagem dos democratas-cristãos para a oposição e a criação de uma coligação inédita entre liberais, socialistas e ecologistas, mais inclinados do que os seus predecessores a uma revisão do passado colonial e claramente a favor de um tipo de relação diferente com Kinshasa. É neste contexto que o sociólogo Ludo De Witte (2000) publica a sua investigação sobre as circunstâncias da morte do primeiro-ministro congolês, ${ }^{3}$ publicação que está na origem da comissão de inquérito parlamentar visando estabelecer oficialmente a responsabilidade do Estado belga nesses acontecimentos. Para compreender o contexto sociopolítico da criação desta comissão de inquérito, aparentemente um caso único na história recente dos países colonizadores, é necessário ter em conta a transformação institucional do Estado: uma estrutura federal em que cada entidade federal se reposiciona em relação à história nacional. Por fim, de maneira concomitante, uma série de manifestações culturais e de livros desses anos interrogam o passado colonial de maneira crítica e informada (Gillet, 2007: 73-75).

Contemporâneo dos acontecimentos políticos acima sublinhados, Lumumba de Raoul Peck (coprodução franco-belga-alemã) estreia em 2000 e participa desse vasto conjunto de textos de diversos tipos que regressam ao passado colonial. Torna-se assim necessário ter em conta este contexto particular a fim de captar em parte os significados da peça e do filme. É preciso também atender às suas especificidades respetivas, pois a análise de uma peça e de um filme numa perspetiva comparada convoca ferramentas

\footnotetext{
3 O original neerlandês foi publicado em 1999 (De Moord op Lumumba), a versão francesa em 2000 e a tradução portuguesa em 2001.
} 
narratológicas diferentes, adaptadas ao seu objeto. Contudo, ambos os bens simbólicos têm em comum o facto de terem evidenciado a importância, por um lado, das representações hegemónicas oriundas das antigas metrópoles e, por outro lado, os jogos de tensão entre a cena oficial construída como tal pelas representações mediáticas dominantes e os bastidores da ação política, onde uma série de atores prepara a queda do governo de Lumumba.

À semelhança do que se passa numa tragédia, a peça e o filme descrevem a queda de um homem de poder, captando-o no momento em que, preso numa rede complexa de causas, está prestes a cair. A escolha da palavra é essencial aqui, pois, se Césaire e Peck basearam as suas produções respetivas num importante trabalho de documentação, transformaram o ator político em personagem de ficção, mais especificamente em personagem de tragédia. Embora Peck tenha iniciado o filme com um cartão em que anuncia que se trata de "uma história verdadeira", tudo na obra contribui para a ficcionalidade: a montagem, a música de fundo, a voz-off de Lumumba a dirigir-se à mulher após a execução. Tanto Une saison au Congo como Lumumba abrem respetivamente com uma cena e uma sequência que assumem o seu estatuto de ficção.

\section{Assumir a ficção para dizer a história}

Sabemos que a cena de abertura numa tragédia tem uma função informativa: ainda que se destine ao duplo recetor de qualquer texto de teatro, visa sobretudo o espetador. Algumas personagens são assim incumbidas de o informar sobre o cronótopo, a identidade e a função das personagens principais. A didascália inicial de Une saison au Congo situa a ação num "bairro africano de Léopoldville" e, do ponto de vista temporal, pouco antes da independência. Césaire trabalha de maneira a induzir um efeito de veracidade ao emaranhar a sua ficção com elementos verídicos. Assim, Lumumba é apresentado como um caixeiro-viajante, isto é, o representante comercial encarregado de vender cerveja Polar, o que a figura histórica foi de facto. Note-se que o dispositivo textual duplica o dispositivo cénico virtual: o bonimenteur está em cena, ator encarregado de vender a sua mercadoria, posição que ele aproveita para resvalar do domínio do comércio para o da política. Dois polícias belgas vigiam esta cena dentro da cena e informam o recetor da identidade do revendedor. O teatro assume-se aqui como lugar de ficção, como ficção a ser feita. Assim, a didascália da cena II indica que, entre idas e vindas, se instala um bar africano enquanto a voz do tocador de sanza, cuja função é a do comentador crítico da ação em curso ou então de anunciador do que se seguirá, se ouve no fora de cena.

Por seu lado, a longa sequência de abertura do filme de Peck divide-se claramente em duas partes. A primeira tende a mostrar, por um lado, que as 
populações locais foram objeto de espoliação e de violências por parte das autoridades coloniais e, por outro lado, através da montagem paralela, que a origem do Estado pós-colonial deve ser procurada no Congo colonial. A sucessão de representações fotográficas e fílmicas é reveladora da intenção inicial do realizador. O filme começa com fotos da época a preto e branco, acompanhadas de uma música de fundo, mostrando a Force Publique em manobras, seguida de uma outra, também a preto e branco, de uma família anónima com ar triste a olhar fixamente para a objetiva. A esta sucede-se, através da figura do esbatimento encadeado, uma curta sequência fílmica mostrando, em grande plano, mãos a segurar um copo de champanhe. Um novo esbatimento encadeado leva o recetor para o período colonial com uma foto de trabalhadores negros a empurrar um carrinho de mão, vigiados por brancos. É de sublinhar que se trata de um postal com a seguinte legenda em francês e neerlandês: "Congo belga: os primeiros meios de transporte". Um outro esbatimento encadeado leva-nos à festa antes da passagem a uma nova foto de um anónimo tirada de frente. Sempre através do esbatimento encadeado passamos a um grande plano de uma mão a cortar um pedaço de carne de uma cabeça de porco. Sucede-se uma série de duas fotografias, a primeira a mostrar duas mulheres agrilhoadas sob a guarda de um soldado da Force Publique e a segunda um homem anónimo frente à câmara. A sequência retorna então à festa, através do esbatimento encadeado, com homens e mulheres, brancos e negros, a comer e a beber. Uma nova série de fotografias da época intervém como contraponto à festa, primeiro a de um homem prostrado no chão, algemado, submetido ao chicote; a esta sucede-se uma que representa três funcionários coloniais com um negro sentado no chão frente a uma mesa sobre a qual jazem dois crânios humanos. Note-se que - algo essencial no âmbito desta análise - o grupo olha para a objetiva da máquina fotográfica. Uma terceira imagem conclui a série: trata-se da execução de um negro anónimo por enforcamento que foi objeto de um postal com a seguinte legenda "Execução de um negro em Boma". A montagem leva então o recetor à cerimónia - vemos aí Mobutu no seu trono rodeado de soldados e de convidados, os da festa vislumbrados no início da sequência. O final desta sequência alterna uma foto, a preto e branco, de um grupo de soldados da Force Publique com os seus oficiais brancos, o retorno ao público da festa frente a Mobutu e uma última foto a preto e branco de um outro público captado numa posição semelhante (trata-se de uma cerimónia colonial). Um esbatimento a negro encerra esta complexa sequência inicial.

Vê-se, desde o início, que Peck põe em cena, à medida que a interroga, a questão da representação. Para o Norte colonial, o Outro colonizado 
praticamente não existiu, a não ser através da representação fotográfica e fílmica (lembranças de família, postais, reportagens). Lumumba não escapou a este vasto sistema de representações e de construções mediáticas, tendo sido apresentado ao público belga como um agitador perigoso vendido aos interesses de Moscovo. Como foi sublinhado por Lassi e Tcheuyap, retornar à figura de Lumumba significa igualmente retornar ao discurso mediático hegemónico a fim de o desconstruir:

A questão central, é preciso dizê-lo, é a da palavra, da narração e da representação. O discurso que justifica o empreendimento imperialista mascarando todas as atrocidades coloniais de obras de beneficência, tal como é ilustrado pela locução do rei dos Belgas, é necessariamente desconstruído. (Lassi e Tcheuyap, 2009: 88; ver igualmente Barr, 2011: 87)

Ter-se-á notado a importância do olhar nas fotos selecionadas por Peck: sujeitos coloniais, todos anónimos, olham fixamente a objetiva da máquina fotográfica e, através dela, o recetor. Que dizem os olhares tristes? Como interpretar a foto de família em que ninguém esboça um sorriso? É a isso que nos convida, igualmente, Peck ao mostrar-nos finalmente o público da festa da qual tivéramos até então apenas segmentos: um grupo, também ele anónimo, fixa a câmara com ar sério, frente a um Mobutu com postura hierática, face imperturbável, separado do público por um cordão de soldados. A figura do esbatimento encadeado, simultaneamente figura de retórica fílmica e efeito de montagem frequentemente associado a uma cinematografia mais clássica (Vernet, 1988: 59-88; Villain, 1991: 114-116), permite aproximar duas épocas, mas igualmente dois níveis de verdade, o da foto a preto e branco do período colonial e o do filme a cores de Peck. Cabe assim ao recetor apreender o sentido produzido pela aproximação: a montagem instaura uma relação lógica de causa efeito entre a situação colonial exibida nas fotos e a situação pós-colonial mostrada pelo filme. Por outras palavras, estamos na representação, mas uma representação próxima, pelo menos após esta abertura, da realidade. O presente explica-se aqui pelo passado.

Ao escolher uma montagem baseada numa figura de referência bem como numa ligação lógica de causalidade, Peck insere Lumumba simultaneamente no cinema da lisibilidade (Aumont e Marie, 2008: 45) e num subgénero cinematográfico, o biopic, fundado nos mesmos princípios narrativos (Bingham, 2010). O pacto entre esta prática e o seu recetor baseia-se, em grande parte, na credibilidade que este dá às informações dadas ao longo do filme, pois terá de acreditar na realidade dos acontecimentos (a conspiração contra Lumumba) sabendo-os falsificados (trata-se de uma 
ficção). É esta exigência que explica a inserção de um cartão no final desta primeira parte da introdução, que resume a história do Congo em duas datas: 1885 (o Congo torna-se propriedade pessoal do rei Leopoldo II) e 1960 (Lumumba torna-se primeiro-ministro). A afirmação que fecha o cartão - "Esta é uma história verdadeira" - tende evidentemente a reforçar a veracidade da narrativa fílmica que se seguirá, uma narrativa que, para provar o seu respeito pela história, tenderá a reforçar a sua lisibilidade, a fazer esquecer que se trata de uma ficção, algo que constitui uma das marcas da cinematografia clássica (Aumont e Marie, 2008: 106). Ora, representar uma parte da vida de Lumumba coloca a questão do que se mostra, e consequentemente do que se oblitera e da maneira de como se mostra. Césaire, por seu lado, multiplicará os efeitos de distanciamento, de mise en abyme, nomeadamente através dos comentários do tocador de sanza, da alternância entre diálogos e partes cantadas, o que obriga o recetor a uma maior vigilância, uma vez que lhe lembram constantemente que está perante uma ficção.

A segunda parte da introdução do filme representa um Lumumba ferido no interior do carro que o leva para o local da sua execução. O que nos é dado aqui é o ponto de vista narrativo que se encarregará da diegese. A personagem autodiegética descreve, através de focalização interna, o que acontecerá ao seu corpo: um plano aproximado mostra Lumumba com a boca fechada, o olhar fixando o vazio, como que dirigido para si próprio, a sua mensagem provindo da banda sonora como se se tratasse do seu espírito. ${ }^{4}$ Este endereçamento tem um duplo recetor: de facto, para lá do tempo, através da ficção, Lumumba dirige-se à sua mulher, mas também, através dela, ao recetor do filme. Duas prolepses de estatuto diferente acompanham as palavras de Lumumba: a primeira mostra os dois mercenários belgas encarregados de desmembrar e fazer desaparecer o corpo de Lumumba e dos seus companheiros; a segunda, alicerçada em imagens de arquivo a preto e branco, representa alguns planos breves de manifestações pró-Lumumba em cidades anónimas na Europa ou nos Estados Unidos. A aproximação entre os dois espaços-tempos através da montagem induz o recetor a conferir-lhes um estatuto de veracidade semelhante, embora a primeira prolepse pertença ao domínio da ficção, ainda que, no essencial, se aproxime do que se passou na altura, enquanto a segunda remete para um outro regime de verdade, o das imagens gravadas logo após o anúncio da morte de Lumumba.

A esta sucede-se uma analepse bastante surpreendente para o recetor, pelo menos para o recetor pouco conhecedor de uma história que envolve

\footnotetext{
${ }^{4}$ A análise fílmica fala a este propósito de focalização mental ou voz interior: "Os pensamentos da personagem intervêm apenas na banda sonora e não na banda visual” (Goliot-Lété e Vanoye, 2007: 37).
} 
múltiplos atores. Reencontramos Lumumba em Léopoldville, pouco após o seu regresso de Accra, em plena discussão com os seus adversários políticos do Katanga. As ameaças de Moïse Tshombe ao futuro Primeiro-Ministro permitem, através da ligação da causalidade, a montagem com a sequência seguinte, onde, sempre em focalização interna, Lumumba relata a sequência de eventos (as palavras acompanham o plano da traseira do camião que transporta os cadáveres dos três homens assim como o material destinado a fazer desaparecer os corpos). É após esta introdução complexa que começa a vasta analepse que conduz o recetor da chegada de Lumumba a Léopoldville até à sua morte.

A partir deste instante, o filme de Peck e a peça de Césaire representam, em parte, o que foram os últimos meses de vida de Lumumba, um e outro dando um ponto de vista sobre a história do Congo independente. As duas obras contribuem, com os meios do teatro e do cinema, para a edificação de um discurso histórico relativo às razões que conduziram à queda do dirigente congolês. Seria errado desvalorizar os textos com base no seu estatuto de ficção: o regime de verdade da ficção difere certamente do da historiografia, como vimos no início, mas não deixa de se tratar de uma verdade, que deve apenas ser analisada com instrumentos diferentes. Como sinalizava há pouco, é necessário compreender que a verdade da ficção depende do contexto no qual essa ficção foi produzida. Por outras palavras, analisar uma peça ou um filme faz sentido, em parte, se tivermos em conta o contexto de enunciação; em parte, pois os significados de um texto (neste sentido tanto importa se se trata de um filme ou de uma tragédia) jogam-se também na análise das suas características formais e simbólicas. Assim, a análise de cenas da peça de Césaire e de sequências do filme de Peck apenas fazem sentido quando inscritas numa totalidade que envolva simultaneamente o texto e as suas estratégias narrativas e retóricas e o contexto da enunciação. Este trabalho sobre a maneira com que a arte produz ela própria discursos sobre a história faz ainda mais sentido quando se trabalha a partir de uma perspetiva comparada, reveladora das características inerentes a uma e outra prática artística.

Sabemos que a fonte de enunciação em Lumumba coloca a diegese do lado da verdade, reivindicando dar realmente conta dos acontecimentos, com os nomes e os lugares a remeter, por exemplo, para referentes identificáveis, com as consequências que podemos bem imaginar quando um ator ainda vivo não se reconhece no seu alter ego da ficção. ${ }^{5}$

\footnotetext{
${ }^{5}$ Foi o caso de Frank Carlucci, segundo secretário da Embaixada dos Estados Unidos, agente da CIA, estacionado no Congo no momento da independência, que desempenhará um papel não negligenciável na queda de Lumumba e na ascensão de Mobutu. Quando o canal privado americano HBO programa o filme em 2002, Carlucci consegue fazer retirar o seu nome da banda sonora e do genérico (Foran, 2003: 162).
} 
Com Une saison au Congo, Césaire não pretendia reproduzir mais ou menos fielmente a realidade, ainda que o trabalho de preparação tenha sido importante, mas dar conta, utilizando a estrutura da tragédia, da ascensão, da queda e da morte de Lumumba. Teve o cuidado de modificar a maior parte dos nomes de personagens o que é certamente uma maneira de tentar evitar certos aborrecimentos, ${ }^{6}$ mas que se pode igualmente perceber no contexto de uma tragédia que pratica constantemente o distanciamento. Com Césaire - no que é uma grande diferença em relação ao filme de Peck - não se verifica uma linha narrativa clássica, ansiosa por atenuar os sinais mais visíveis da ficção. O teatro de Césaire é, pelo contrário, todo marcado pelo selo da mise en abyme, o teatro dentro do teatro, o recurso à artificialidade assumida como tal. Por outras palavras, fale do rei Christophe, de Lumumba ou reescreva Shakespeare, o dramaturgo impede o seu recetor de aderir de maneira acrítica à fábula. Os diversos artifícios levam o mesmo recetor a questionar os pontos de vista, o discurso dominante, as atitudes e as tomadas de posição, em suma, a envolver-se por e numa tragédia pouco inclinada à catarse de emoções. ${ }^{7}$

A peça e o filme contam assim, em parte, a história e, em certos momentos, contam-na de maneira semelhante, como se Pascal Bonitzer, o autor do guião de Lumumba, se tivesse dedicado, nessas alturas, a uma releitura da tragédia de Césaire. É assim na sequência da prisão, durante a qual Lumumba é insultado e maltratado por dois guardas, cuja ação é interrompida pelo diretor da prisão (16'23). Este último anuncia ao prisioneiro a sua libertação por ordem de Bruxelas de modo a poder participar, enquanto presidente do Movimento Nacional Congolês, nos trabalhos da Mesa Redonda. Uma aproximação minuciosa faz aqui de Une saison au Congo o palimpsesto que perfura Lumumba: os dois carcereiros do filme insultam Lumumba de maneira idêntica, um deles descobre um texto curto no qual o prisioneiro reclama a sua libertação a fim de poder deslocar-se à Bélgica para participar nas negociações relativas ao futuro

\footnotetext{
${ }^{6}$ Segundo Romuald Fonkoua, Césaire modificou o nome de Mobutu para Mokutu a fim de evitar um processo de difamação por parte do presidente do Zaire. Por outro lado, esta peça foi a única das três tragédias do poder a não ter passado pela pré-publicação na revista Présence africaine, tendo sido diretamente publicada na Seuil. Segundo o seu biógrafo, o escritor teria assim querido proteger a casa de edição de eventuais represálias financeiras (Fonkoua, 2010: 336-338).

${ }^{7}$ Césaire atribuía ao teatro um papel de primeiro plano nos novos Estados independentes: tratava-se, por um lado, de, através do texto, educar o público, adverti-lo para os perigos que pairavam sobre os Estados em questão e de contribuir assim para a construção do Estado; por outro lado, tratava-se de importar, pelas necessidades da encenação, tecnologias indispensáveis para a modernização do país (Curto, 2011: 158-159).
} 
da colónia, o que induz um diálogo no qual as palavras trocadas, assim como os gestos, são praticamente idênticos. ${ }^{8}$

Tanto a peça como o filme passam de seguida do espaço ficcional congolês para o de Bruxelas, durante as negociações belgo-congolesas de janeiro-fevereiro de 1960. Para indicar a mudança espacial, Césaire utiliza uma técnica recorrente na linguagem teatral: "Um aviso cai da varanda; lê-se: 'Bruxelas, sala da Mesa-Redonda'” (Césaire, 1973: 22). Este tipo de artifício faz parte dos códigos do teatro e não impede a adesão do recetor, quer seja o leitor ou o espetador. O espaço teatral tem, de facto, como particularidade precisar apenas de uma convenção para funcionar: se uma didascália técnica, como é o caso nesta ocorrência, indica que a ação tem lugar em Bruxelas, o espaço ficcional surge imediatamente como tal. Este espaço dramático começa a existir mesmo junto de um leitor que, neste ponto, não se distingue do leitor de uma obra histórica sobre o mesmo tema. O cinema, por sua vez, não consegue fazer a economia da representação detalhada do espaço ficcional realista (existem certamente exceções da parte do cinema de autor). Peck construirá o seu cenário de maneira a tornar plausível - o fazer como se do cinema da ilusão o salto no espaço e no tempo (os meios de transporte, a roupa, os móveis pretendem invocar a Bélgica de início dos anos 1960). Ora, trata-se de apresentar o plausível, não o verdadeiro: o espetador aceita acreditar ainda mais por isso (o cenário, a história, as personagens) parecer plausível. É possivelmente neste ponto que o trabalho do cineasta e da sua equipa técnica se aproxima mais do trabalho do historiador quando este tenta devolver uma época através da descrição tão fiel quanto possível do que ela foi materialmente.

No que diz respeito à Mesa Redonda, Césaire e Peck optam por representar não a versão oficial das negociações mas as acomodações, os compromissos, as tensões presentes nos bastidores. Além disso, Césaire coloca os seus "banqueiros" na "antecâmara" da sala de negociações, uma vez que

\footnotetext{
${ }^{8}$ Eis o que é dito na peça: "Primeiro carcereiro: Nada mal, hã? (bate-lhe) Imaginas-te em Bruxelas, selvagem? E o que é que dirias ao rei se o visses? O que é que dirias a Bwana Kitoko?/ Segundo carcereiro: (a bater) Sem dúvida que quer ser ministro! (Ri-se) Imaginas-te excelência, macaco! Excelência." (Césaire, 1973: 21). A comparação com a sequência correspondente no filme é esclarecedora: "Primeiro carcereiro: Imaginas-te em Bruxelas assim, hã? E dizias o quê ao rei, hã? Dizias o quê a Bwana Kitoko? Segundo carcereiro: (a brutalizar Lumumba) Ah, quer ser ministro! Querem todos ser ministros. Queres condecorações, vamos condecorar-te (tocando no peito de Lumumba com a matraca) Primeiro carcereiro: Queres que te chamem excelência, é isso? Macaco!" (os dois homem batem em Lumumba) (Peck, 2000: 17'37-18'22). De seguida, como na peça de Césaire, o diretor da prisão interrompe os dois guardas e anuncia a Lumumba que é livre e que irá apanhar o avião para Bruxelas no dia seguinte.
} 
é precisamente ali que, segundo o seu ponto de vista, se joga o futuro do Congo. Para o capitalismo belga e o mundo da finança, a independência não representa mais do que uma vicissitude que teria de ser gerida de acordo com os seus interesses. O "quarto banqueiro" resume numa tirada o que será o neocolonialismo no contexto de um Estado que dispõe de sinais exteriores de independência. Notar-se-á que, no original francês, a personagem se exprime em alexandrinos, forma poética de referência para a cultura burguesa. Césaire salienta assim que a forma poética nunca é neutra e comporta, ela também, a marca da cultura colonial:

Siga a ideia: o que querem eles? Postos, títulos,

Presidentes, deputados, senadores, ministros!

Finalmente o matabich! Bem! Carro, conta no banco

Vivendas, salários chorudos, não vou poupar.

Axioma, e isso é o importante: empanturrem-nos!

Resultado: o coração amolece-lhes, o humor torna-se-lhes suave.

Estão a ver pouco a pouco aonde o sistema nos leva:

Entre o povo deles e nós, ergue-se a sua tropa.

Se, pelo menos, com eles, na falta de amizade

Neste século ingrato sentimento obsoleto

Sabemos amarrar os nós da cumplicidade.

(Césaire, 1973: 24)

Após esta explicação poética, o coro dos banqueiros grita "Hurra! Hurra! Viva a independência!". Toda a quarta cena do primeiro ato condensa, segundo uma estética do domínio do grotesco, a emergência de um novo regime de dependência que é posto em prática em numerosas antigas colónias: o neocolonialismo, cujos mecanismos Nkrumah descreve no momento em que Césaire prepara e escreve Une saison au Congo. Nesta cena, como em toda a tragédia, o texto produz mudanças tanto no âmbito do que é representado (os quatro ou cinco homens da didascália técnica estão "disfarçados de banqueiros de caricatura: casaco, chapéu alto, grande charuto”) como do modo de representação (os banqueiros exprimem-se em alexandrinos), o que, impede a adesão completa à ficção e desperta o sentido crítico do recetor. Este fica assim mais inclinado para se interrogar sobre o que se joga nos bastidores das negociações belgo-congolesas: Césaire parece dizer-nos que nem tudo é o que parece nesta cena grotesca com implicações éticas ainda mais importantes, já que a cena seguinte é a da festa da independência em Léopoldville. A "multidão aplaudindo e alegre" celebra a sua independência ao ritmo de Indépendance Cha Cha, rumba famosa de Grand Kallé 
e do African Jazz, enquanto o recetor já sabe, após a cena anterior, que a festa será de curta duração.

Neste ponto, Peck procede de maneira distinta, pois a sequência da Mesa Redonda é estruturada em torno de três espaços: a sala onde os representantes congoleses negociam, aquela em que negoceiam os representantes do governo belga e o espaço das cozinhas e dos servidores. Esta última representa metaforicamente os bastidores da cena principal, isto é, junto da instância da receção, a presença do terceiro espaço significa ao mesmo tempo pelo que é, mas mais fundamentalmente remete parcialmente para o projeto de Peck: dar acesso aos bastidores da história. Se a estética é sempre a da lisibilidade, do apagamento das marcas da ficção, não deixa de permanecer uma ficção com os seus efeitos de acentuação, omissão e ainda de elipse. Além disso, ao recorrer à montagem alternada, Peck passa de um espaço a outro e, confrontando os pontos de vista belga e congolês, induz junto do recetor a tomada de consciência de que se, de um lado, se canta e se festeja, do outro se prepara já uma eventual intervenção neocolonial. A sequência da Mesa Redonda fecha-se com a delegação congolesa a cantar e dançar ao ritmo de Indépendance Cha Cha, música que permite a ligação com a sequência seguinte em Léopoldville na véspera da independência. Mais uma vez, a proximidade entre os dois textos é notória, tanto na estrutura (semelhanças na transição entre Bruxelas e Léopoldville) como no corpo do próprio texto, onde as ameaças de intervenção belga no Congo são formuladas de maneira bastante idêntica.

\section{Considerações finais}

Após esta análise, podemos afirmar que Lumumba e Une saison au Congo, no que é um reflexo da sua complexidade, significam em diversos níveis e requerem, se quisermos pôr em evidência essa riqueza polissémica, a utilização de diversos utensílios analíticos. Para captar o que nos dizem da relação da tragédia e do filme de ficção com a história, é necessário, como vimos, circular constantemente entre leitura interna (para, por exemplo, pôr em evidência a importância de uma figura cinematográfica como o esbatimento encadeado) e leitura externa (para ter em conta os contextos diferentes em que se inscrevem as duas obras). Se a ficção diz a história tal como nela participa, impõe igualmente uma distância, a da crítica, em relação à história oficial, ao arquivo colonial, e, pelo seu poder de amplificação, consegue implicar (mas também informar e comover) a comunidade de maneira distinta de um livro de história.

Além deste trabalho de releitura do passado, a peça de Césaire e o filme de Peck tendem igualmente a dar uma sepultura à figura sem sepultura, 
o que, recordemos brevemente, é muito frequente na literatura e no cinema do trauma. A partir deste ponto de vista, a arte desempenha um papel essencial pois permite, com os meios que são os seus, figurar como um lugar de memória. Ora, no contexto social de referência, como sublinha o historiador congolês Omasombo Tshonda, a ausência de sepultura para Lumumba tal como a não transmissão da história junto da população impediram o processo de luto coletivo (2004: 245$)$. Neste contexto, a literatura e o cinema veem-se dotados de um excedente de significação, pois conseguem prestar testemunho de uma certa permanência do ser ausente junto da comunidade. O regime de verdade inerente à história certamente não tem por objeto principal servir de apoio à memória subjetiva e afetiva de um grupo social, mas, ao evitar o debate com esta última, não favorece o trabalho de luto necessário. É o que Gauthier de Villers censurou nos peritos da comissão de inquérito parlamentar sobre as circunstâncias da morte de Lumumba:

Os peritos da comissão, ao contrário do que tinha feito a comissão sul-africana Truth and Reconciliation [...], não tentaram permitir uma confrontação entre a sua verdade de ordem factual ou jurídica e as verdades imbuídas da subjetividade dos atores e testemunhas da época e de todos os que hoje mantêm a sua memória, uma confrontação que, todavia, só ela poderia ter permitido contemplar este trabalho de "terapia " coletiva, portanto o luto [...]. (de Villers, 2004: 217)

Parece ser claro que a literatura e o cinema desempenham um papel importante não apenas na transmissão de uma memória truncada, dominada durante muito tempo por uma historiografia de origem colonial, mas também na edificação de um discurso histórico. O facto de Césaire e Peck não serem congoleses dota as suas obras de mais um significado. Oriundos das Caraíbas (Martinica no caso do primeiro e Haiti no do segundo), inscrevem-se numa prática artística pós-colonial com fronteiras permeáveis, onde o texto vem a significar fora e dentro delas. É revelador, a partir desta perspetiva, que um historiador da literatura congolesa integre sem qualquer problema a obra de Césaire na história do teatro na República Democrática do Congo (Kadima-Nzuji, 2003). Se Fanon já pressentira o que a morte de Lumumba viria a significar para o conjunto do continente africano, ou seja, para lá das fronteiras estritas da RDC, Aimé Césaire e Raoul Peck contribuem, pela sua ancoragem no Atlântico negro, para universalizar a luta do homem de exceção. É possível considerar Une saison au Congo e Lumumba tanto como testemunhos válidos não somente da memória congolesa contemporânea mas igualmente de 
outras comunidades no mundo. ${ }^{9}$ Tal como se verifica com a memória da Shoah, quanto mais o assassinato de Lumumba e os crimes do colonialismo recuam no tempo, mais pertencem às novas gerações, cuja responsabilidade moral é assim essencial, pois cabe-lhes a reativação, ou não, da memória do trauma. É o que Ribeiro sublinha no contexto da memória contemporânea da Shoah. Tarde ou cedo, a história dirá o conjunto dos factos relativos ao acontecimento violento, descreverá as suas origens, o desenrolar e as consequências, e é então, muito depois dos feitos e às gerações posteriores, que se colocará a questão da natureza da ligação ao acontecimento:

As questões que permanecem e permanecerão em aberto, as perguntas para as quais não haverá talvez nunca resposta satisfatória - e que, por isso, demarcam abertamente os limites da teoria -, não são, pois, da ordem da averiguação dos factos nem da simples interpretação histórica, mas sim da ordem da memória e da pós-memória, isto é, da ordem de uma relação com o passado estruturada a partir do envolvimento presente de sujeitos concretos. (Ribeiro, 2010: 14)

A peça de Césaire e o filme de Peck reativam assim, em parte, a atualidade do pensamento de Lumumba junto das novas gerações de recetores no interior e no exterior das fronteiras congolesas, participando da emergência de uma memória contemporânea do acontecimento violento. Se através da ficção, a biografia e os textos do homem político ainda vierem a significar algo de essencial, é igualmente porque Lumumba defendeu a emancipação não apenas para o seu país, mas também para todos os oprimidos da terra. E lembrá-lo não é um dos méritos menores da arte.

\section{Referências bibliográficas}

Aumont, Jacques; Marie, Michel (2008), L'analyse des films. Paris: Armand Colin.

Barr, Burlin (2011), "Raoul Peck's Lumumba and Lumumba: La mort du prophète: On Cultural Amnesia and Historial Erasure", African Studies Review, 54(1), April, 85-116. Bingham, Dennis (2010), Whose Lives Are They Anyway? The Biopic as Contemporary Film Genre. New York: Rutgers University Press.

\footnotetext{
${ }_{9}^{9} \mathrm{Na}$ sua crítica, Julia Watson lembra que, aquando da estreia em Los Angeles em julho de 2001, o realizador do Haiti explicou que numerosos espetadores oriundos do Sul reconheciam em Lumumba um dos seus: "Falando com um certa dose de ironia, Peck notou que nos países em desenvolvimento por esse mundo fora - nas Caraíbas e na América Latina, bem como em África - o público encontrava de imediato paralelos com as suas próprias histórias nacionais na história da ascensão e queda meteórica de Lumumba e nos jogos de intriga internacional que se jogaram em torno dele." (Watson, 2002: 234).
} 
Boucheron, Patrick (2011), “On nomme littérature la fragilité de l'histoire”, Le Débat, 3(165), 41-56.

Braeckman, Colette (1992), Le dinosaure. Le Zaïre de Mobutu. Paris: Fayard.

Césaire, Aimé (1973), Une saison au Congo. Paris: Seuil.

Coquio, Catherine (2013), "Le territoire des ogres", Fabula/Les Colloques, Littérature et Histoire en débats. Consultado a 02.01.2014, em http://www.fabula.org/colloques/ document2150.php.

Curto, Roxanna (2011), “The Science of Illusion-making in Aimé Césaire’s La Tragédie du Roi Christophe and Une Tempête”, Research in African Literatures, 42(1), 154-171.

de Villers, Gauthier (2004), "Histoire, justice et politique. À propos de la commission d'enquête sur l'assassinat de Patrice Lumumba, instituée par la Chambre belge des représentants", Cabiers d'Études Africaines, 1(173-174), 193-220.

De Witte, Ludo (2000), L'assassinat de Lumumba. Paris: Karthala.

Fanon, Frantz (2006), Pour la révolution africaine. Écrits politiques. Paris: La Découverte.

Fonkoua, Romuald (2010), Aimé Césaire. Paris: Perrin.

Foran, Johan (2003), “Lumumba by Raoul Peck”, Journal of Haitian Studies, 9(1), Spring, 158-162.

Gillet, Florence (2007), “Contrepoint. L'histoire coloniale en débat: examen d'une Belgique en repentir”, Mouvements, 3(51), 70-77.

Goliot-Lété, Anne; Vanoye, Francis (2007), Précis d'analyse filmique. Paris: Armand Colin.

Guidée, Raphaëlle (2013), "L'écriture contemporaine de la violence extrême: à propos d'un malentendu entre littérature et historiographie", Fabula/Les Colloques, Littérature et Histoire en débats. Consultado a 07.01.2014, em http://www.fabula. org/colloques/document2086.php.

Jewsiewicki, Bogumil (1996), "Corps interdits. La représentation christique de Lumumba comme rédempteur du peuple zaïrois”, Cahiers d'Études Africaines, 36(141-142), 113-142.

Kadima-Nzuji, Mukala (2003), “Théâtre congolais et réécriture de l'histoire nationale”, in Mukala Kadima-Nzuji; Sélom Komlan Gbanou (orgs.), L'Afrique au miroir des littératures, des sciences de l'bomme et de la société. Mélanges offerts à V.Y. Mudimbe. Paris: L'Harmattan \& A.M.L Éditions, 335-353.

Lassi, Étienne-Marie; Tcheuyap, Alexie (2009), "Le prophète, son récit et l'histoire: Lumumba au cinéma”, Revue de l'université de Moncton, 40(1), 83-105.

Mégevand, Martin (2009), "Violence et dramaturgies postcoloniales", Littérature, 2(154), 91-107.

Nora, Pierre (2011), "Histoire et roman: où passent les frontières?”, Le Débat, 3(165), 6-12.

Omasombo Tshonda, Jean (2004), "Lumumba, drame sans fin et deuil inachevé de la colonisation”, Cabiers d'études africaines, 1(173-174), 221-261. 
Ozouf, Mona (2011), "Récit des romanciers, récit des historiens”, Le Débat, 3(165), 13-25.

Peck, Raoul (real.) (2000), Peck, Raoul; Bonitzer, Pascal (guião), Lumumba, 1 h55.

Ribeiro, António Sousa (2010), "Memória, identidade e representação: Os limites da teoria e a construção do testemunho”, Revista Crítica de Ciências Sociais, 88, 9-21.

Ricœur, Paul (2000), La mémoire, l'bistoire, l'oubli. Paris: Seuil.

Vernet, Marc (1988), De l'invisible au cinéma. Figures de l'absence. Paris: Cahiers du cinéma.

Villain, Dominique (1991), Le montage au cinéma. Paris: Cahiers du cinéma.

Watson, Julia (2002), "Raoul Peck's Lumumba: A Film for our Times”, Research in African Literatures, Summer, 33(2), 230-235.

Artigo recebido a 11.09.2014

Aprovado para publicação a 19.01.2015

\section{Fabrice Schurmans}

Centro de Estudos Sociais, Universidade de Coimbra

Colégio de S. Jerónimo, Largo D. Dinis, Apartado 3087, 3000-995 Coimbra, Portugal

Contacto: fschurmans@yahoo.fr 